involvement with the graduate after he or she enters the agency.

Fourthly, we have not yet established a tradition of post-qualification study. The first steps have been taken in each university with varying but not widespread results. Until we have developed postgraduate study and research the vitality of social work education in New Zealand must fall below its real potential.

In spite of these last few comments, or perhaps because of them, I feel social work education in New Zealand is alive and well. Tihe mauri ora!

I would like to thank the Editor for giving me the opportunity to contribute to this issue as a kind of poroporoaki on the eve of my retirement.

\title{
Social work education in New Zealand: Ideological bases of current debates
}

Jennie Pilalis

Lecturer in Social Work, Victoria University of Wellington.

'The Question is,' said Alice, 'whether you can make words mean so many different things.'

'The Question is,' said Humpty Dumpty, 'which is to be master. That is all.'

Social work education in New Zealand has come under review (University Grants Committee, 1981, p.21) and debates are emerging in some circles as to the most desirable direction for social work education to follow, now and in the future (SWTC discussion papers, 1981, 1982, p.20). The debates have exposed the conflicting views regarding the goals and methods of social work education. Furthermore, they have raised questions as to who finally decides the goals and methods to be pursued.

Different educational and social work theories are based on different visions of the ideal, and lead to different systems of operation. In order to understand the rationale for any educational or social work system, we need to be clearer about its ideological base and its link to different groups of people - their way of thinking, their way of viewing the world.

\section{Alternative education ideologies in social work education}

Table one ${ }^{1}$ distinguishes five 'ideal type' ideologies evident in current educational perspectives. These positions rationalise different emphases regarding the goals of educational policies and the desired structures for implementing these policies. Each ideological position is favoured by a particular social position or class (Young, 1971, p.25). This paper will briefly examine the nature of each position and its implications for models of social work education, models of the organisation of the social work community, views regarding the nature

No table provided. 
of social work and the ideal social work role. It will then reflect on this analysis in relation to several recurrent themes which emerge regarding the concepts of education, training, socialisation, and indoctrination and regarding the historical development of social work education in New Zealand.

\section{Conservative ideologies}

Conservative ideology defines the main goal of education as the development of social character as defined by the aristocracy and gentry classes in society. Williams (1961, p.24) suggests this model was particularly dominant in English history when education was attached to churches, then later to universities with the development of law, medicine and philosophy.

The conservative ideology is evident in views which argue that the best preparation for social work is a wide-ranging, non-vocational education which develops in the potential social worker, the appropriate morals, social character and values. The purpose of such education is to prepare the social worker to 'rescue' and 'minister' to the 'socially inadequate individuals' who comprise 'societal loose-ends and casualties' (Pritchard and Taylor, 1978, p.13). Social work is viewed as a moral-ethical activity. Skills are applied to clients who play a passive role in the helping relationship. Specific social work skills and processes are seen to be best learned on-the-job in the agencies.

Any social work associations are therefore based on shared interests and eligibility is defined in terms of this interest, usually as demonstrated by involvement in social work activity as an employee or volunteer.

\section{Bourgeois ideologies}

Johnson (1972, p.8) suggests that with the increase in power of merchant and professional classes since the industrial revolution, the ideology of the bourgeois, in the form of professionalism, has gained an influence. The bourgeois favour higher vocational and professional courses, preferably set in universities. In fact, a significant element in the professionalised status of an occupation is the establishment of university-based courses (Wilensky, 1964, p.23).

Education, from this perspective, provides access to desired social positions. As merchant and professional classes hold power in our current social structure, professional social positions are highly desired. This view of the goal of social work education is typified by social work practitioners who say they are enrolling in a course in order to gain promotion.

Those holding this ideological position favour university qualifications as desirable for all social workers. The implication for the social workers' association is that membership be based on professional qualifications. Accreditation of courses to ensure professional standards are maintained, and ultimately registration and licensing of practitioners follows from this perspective.

In its extreme, this position views the medical profession as the model to which social work should aspire. A psycho-pathological view of the nature of social work is thus held, the 
social work role being to treat people so that they adjust to the dominant norms for clients, clients being dependent on the social worker.

\section{Liberal ideologies}

Liberal ideologies in education emphasise the importance of the rights and freedom of the individual, equality of opportunity, distributive justice, and thus compensatory education. Liberals believe that inequality in society can be decreased through education, if education is open to all. The goal is the production of moral rational and autonomous individuals.

Liberals wish to make access to desired social positions available to a wider range of person than the bourgeois by providing a wider range of accredited social work courses, in a variety of educational settings. Consequently, a liberal position favours less rigidly controlled associations of social workers, membership criteria being open to all who express a wish to be involved.

A psycho-social view of the nature of social work is currently associated with the liberal perspective. This stresses the influence of social and environmental factors, as well as the psychological, on client situations. The social worker is thus seen as an agent of reform, helping both the individual and society evolve along more human ways within current political structures (Pritchard and Taylor, 1978, p.13). Clients are seen as interdependent in this process, the helping relationship being more reciprocal.

\section{Marxist ideologies}

The Marxist position believes that the liberation of oppressed persons and groups requires a revolution which destroys the capitalist system. They do not agree with the liberal view that reforms and individual effort will achieve this aim as current inequalities are seen to be an intrinsic product of the capitalist socio-economic system. The Marxist perspective sees society as characterised by class conflicts of interest. Workers are seen as the oppressed group as they do not control the means of production. Education is seen to perpetuate inequalities and the oppression of working classes, as it is in the control of the bourgeois, the ruling class.

This ideological position favours educational policies which involve student choice and participation in decisions regarding course structure and content (Williams, 1961, p.24). Courses must be made more relevant to students and the working classes, the latter comprising the bulk of social work clientele.

The purpose of social work education is to teach social work recruits how to dispose of their conservative, bourgeois, or liberal illusions and adopt a 'correct' political perspective and thus become a part of the revolutionary movement. It must also raise awareness of the fundamental conflicts of interest in our society (Pritchard and Taylor, 1978, p.13).

The social workers are required to develop collective action with working class groups of clients, and share their skills with those clients. It is imperative, in the Marxist view, that social work develops a political network with workers' groups, thus unions of social workers are favoured rather than professional associations. 


\section{Critical-libertarian ideologies}

This position encompasses a diversity of recently developed ideological perspectives which extend the Marxist views to encompass all oppressed groups, not only workers. The most commonly identified additional groups are blacks and women. The critical-libertarian position, as does the Marxist position, recognises the conflicts in society. It enhances the political-ideological component of education even further (Resnick, 1980, p.16).

The most common educational policy associated with this position is that of Paulo Freire (1972, p.4; 1973, p.5). Freire defines education as a dialogical process which results in conscientisation or 'an awakening of consciousness, a change of mentality involving an accurate, realistic awareness of one's place in nature and society'; the capacity to analyse its causes and consequences critically, comparing them with other situations and possibilities; and a logical action aimed at transformation. Psychologically, it entails an awareness of one's dignity (Resnick 1980, p.16). Education is thus a tool for changing societies. It develops a provocative and revolutionary role when it becomes a process of enquiring about the world as it is experienced, rather than a process of seeing the world as a static object, apart from man.

In Latin America, some schools of social work use this model, the process of conscientisation assuming a central place in the curricula. Theory and practice, reflection and action, are not divorced but become a 'praxis', a continuous process of critical reflection and then action upon that reflection (Lusk, 1981, p.10). Students live their experience with the oppressed. Through dialogical action with these groups they develop a praxis or action framework.

Estrada de Caro, a Peruvian Professor of Social Work, has identified three implications of this ideological position for social work (Lusk 1981, p.10). These are a change in the class character of the profession, a change of method and a shift in practice. The class character shifts to an explicit identification with the masses so as to incorporate their goals. The method rejects casework, groupwork and community organisation as 'anti-scientific' and replaces them with 'science' of dialectical materialism. The practice is modified by changing objectives to 'the battle against the exploiters and their state' and 'organisation, conscientisation, and mobilisation of the exploited' (Lusk, 1981, p.10).

The role of the social worker is thus a co-learner, the clients being active and subjective in the social work process. The goal is emancipation of the oppressed through group action. The essential nature of social work is ideological and educational, in this political sense (Resnick, 1980, p.16).

The type of association of social workers favoured is thus an association which identifies and joins with the oppressed groups. Conscientisation of members is central to the association's activities.

\section{Education, training, socialisation or indoctrination? (or 'Can you make words mean many different things?')}

Within these differing ideological perspectives are differing emphases regarding the nature of the learning process in the attainment of a social work qualification. This learning process 
has been described as 'education', 'training', 'socialisation' and 'indoctrination' in social work literature.

R.S. Peters (1970, p.12) distinguishes between the goals of 'education' and 'training'. He suggests that the term 'training' most appropriately refers to learning processes which result in the development of competence in a limited skill or mode of thought. 'Education' suggests a linkage with a wider system of beliefs. A man with a 'trained mind' is one who can tackle problems in a rigorous and competent way. A man with an 'educated mind' is one who is more aware of the different facets and dimensions of such problems' (Peters, 1970, p.12, p.34). Learning, in the sense of 'training' involves the acquisition of skills which are to be used for a specific end. In 'education', students not only acquire knowledge, skills and ways of behaving, but acquire these in a way which involves understanding and evaluating the rationale underlying the knowledge skills and ways of behaving. 'Education' thus involves the development of a 'critical edge' to minds of social workers (Hardy, 1981, p.6).

Those who favour an 'on-the-job' or apprenticeship model of preparation for social work (based on a conservative ideology) appear to favour the dominance of the training process, sometimes based on prior, general non-vocational 'education'. Specific skills are developed in specific short courses or in the process of working. The skills are to be used for the agency and clients of that agency. Education as the prime process in the preparation of social workers is the common rationale for university-based qualifying courses.

Social work courses are also seen to be processes of 'socialisation' into the profession of social work, or alternatively 'indoctrination'. Adherents to a bourgeois ideology, particularly emphasise the importance of 'socialisation' into the profession's values as the primary goal of courses. Through this process, students take on the values and practices sanctioned by the profession they are entering. The professional group, therefore, needs to control the content and structure of courses through accreditation, and subsequent registration of practitioners. With current questioning of the values of professionalism in social work, the methods and results of this socialisation process are being questioned. 'Indoctrination' is identified as a form of socialisation which uses 'social power and control of the learning environment to promote anxiety, confusion and identity crises' (Raynor, 1977, p.15). Coercion is thus involved, which is antithetical to the education process. Education implies motivation or a willingness to be involved in a process of learning and change, and the development of an ability to be critically aware of that process. The crucial factor which determines whether courses are processes of 'education' or 'indoctrination' is the means by which the course is carried out and the commitment of the student.

There appears to be a place for both 'education' and 'training' in New Zealand social work, both being processes of socialisation with the possibility of a 'critical edge'. The 'socialisation' process can be seen to have paramount importance within both bourgeois and Marxist perspectives. One results in the adherence to values of professional classes and the other to those of working classes, both being susceptible to becoming processes of 'indoctrination'. The conservative position gives prime importance to 'training' in preparation for social work. 'Education' can be seen to be the goal of liberal and critical-libertarian ideologies, both defining 'education' differently. (Of course, an element of 'socialisation' is present in all these typologies.) 
We, indeed, can make words mean different things but, as Humpty Dumpty so wisely replied to Alice, the basic question is 'which is to be the master. That is all.' Which ideological perspective or perspectives (and thus meanings applied to social work education and social work itself) have been the master or masters in the development of social work education in New Zealand to date, and who will be the master in the future? That is the vital issue to be debated now. This is a question which warrants more detailed analysis and research than this paper can hope to provide. However, this exploration of the history of New Zealand social work education will provide a basis for such further investigation.

\section{Historical periods in New Zealand social work education (or 'Who has been the master?')}

Four phases in New Zealand social work education can be identified. Firstly, the pre-1949 period; secondly, the 1950-1973 period; thirdly the 1973-1981 period; and finally the current $1982+$ period. The pre-1949 period was characterised by the on-the-job apprenticeship type of 'training' of social workers, with no formal qualifications or vocational courses. One may hypothesise that the conservative ideology prevailed at this point, and thus a moral-ethical view of the nature of social work.

In 1950, the first university-based course was developed at Victoria University at Wellington and was to remain the only one in the country for the next 25 years. Meanwhile, university-based courses were developed in England, USA and Australia (Kendall, 1978, p.9). The changing focus of this sole education course is described in detail by McCreary (1971, p.11) as moving from a social administrative role for social workers to a psycho-pathological and psycho-social view of their role.

It could be conjectured that both the bourgeois and conservative perspectives were vying for mastership in New Zealand social work during this period. The bulk of social work employees did not undergo vocational training in formal courses, but learnt on the job or in in-service courses run by the Department of Social Welfare's Tiromoana and Taranaki House or the agency's training offices. Those who did attain the only university qualification (a diploma) were more eligible for desired promotions to positions of power in social work agencies. These people formed the nucleus for the development of the New Zealand Association of Social Workers in 1963. This move, plus the awareness that the welfare state was not solving social problems and relative economic affluence in the 1960s contributed to the emergence of the third phase in our social work educational history (Crockett, 1977, p.3).

In 1973 the Social Work Training Council (note 'training') was formed which recommended the development of more university-based courses and an accreditation system. Thus the period 1973-1981 saw the rapid expansion of university-based courses (MA programmes at Auckland and Victoria University, 1975; BSW at Massey University, 1976; DipSW and MSW at Canterbury University, 1976). A large increase, in relation to past periods, of qualified social workers followed (Crockett, 1977, p.3). However, 78 percent of social service workers remained without any professional qualifications in 1981 (Rochford and Robb, 1981, p.18).

The main impetus for these developments, it could be hypothesised, came from the dominant influence of the bourgeois ideology in the social work community, and amongst 
related occupations, at this time which favoured the professionalisation of the social work occupation. A sympathetic Minister of Social Welfare was also important, to ensure availability of finance (Crockett, 1977, p.3).

However, this rapid expansion of courses has also set the scene for the stronger emergence of liberal ideologies, which were gaining credence in society and education at this time. Towards the end of this phase, we, therefore, have the Social Work Training Council (supported by the report to the University Grants Committee Review, 1981:21) favouring the development of a 'mosaic of courses', open to a wider variety of people and based in a wider variety of institutions. This model is currently being actioned with the establishment of the first teacher's-college-based course (in Auckland, 1982).

University-based courses are set up as part of the professionalisation of occupations (Wilensky, 1964, p.23). However, it appears that this move in New Zealand social work education has had important repercussions which amount to a 'silent revolution' in New Zealand social work systems. The 'revolution' has been 'silent' in the sense that its presence is felt in many circles, but appears to be rarely confronted and dealt with in a positive manner.

Two aspects of these repercussions will be discussed here. Johnson (1972, p.8) pointed out that the development of university-based courses in fact create a 'multi-portal entry system' into occupational groups, if other avenues of entry are maintained. In New Zealand the largest number of entrants to social work still enter directly via selection for a social work position with an employing agency. With the development of a BSW degree (designed primarily as a pre-entry course) and the increase in diploma and masterate students, other avenues of entry to social work have developed, and become prestigious. The question now is 'who is to be master of the selection process?' - university teachers, agency administrators or the Social Work Training Council? Or does the New Zealand social work community favour a multi-portal entry system where there are many masters? The answer to these questions are required in the 1982 + period of social work education in order to decide whether we favour more pre-entry courses or more post-entry qualifying courses. A further related issue to emerge is whether fully extramural and part-time courses also be expanded.

The differing policies of employing bodies appear to support different sides of this debate. Hospital boards, for example, are increasingly only employing those who already hold a recognised social work qualification. They are also decreasing (or even ceasing) the system of paying an employee to attend a full-time qualifying course. Thus pre-entry qualifications seem to be desired. However, the Department of Social Welfare continues to employ persons without qualifications in social work. In-service 'training' is then provided and a select few are sponsored on salary to attend recognised full-time qualifying courses. Thus post-entry qualifying courses seem to be favoured.

The Social Work Training Council was set up to advise on training needs and co-ordinate provisions. It appears that more co-ordination is required between the SWTC, university teachers and agency administrators if future directions for social work education are to be rationally planned. For such co-ordination to develop, more open acknowledgement of debates and wider participation in these is required. 
Another aspect of this 'silent revolution', following the increase in university-based courses, is ideological. Current university courses enhance the 'education' process by encouraging a critical understanding of social work amongst students and teachers. With the increase in university-based students and teachers more New Zealand social workers are becoming open to the critical ideologies in social work and education today. This process has no doubt been enhanced by the location of courses in sociology departments. Since the early 1970's Sociology has been influenced by Marxist and critical-libertarian perspectives. They have highlighted alternative phenomenologies and the ideological dimensions to sociology and knowledge (Bernbaum, 1977, p.2) and thus to social work.

These developments have set the stage for the fourth stage in social work education, a phase which we are only just entering. With the current presence of five alternative ideological perspectives on social work and social work education (each ensuring the continued representation of different historical stages in the occupation in New Zealand), this period could either become a period of rational debate between ideological positions or a period of competing 'vested interests' arguing for the continuance of their views and practices in order to maintain their own privileged positions.

\section{Further directions: Rational debate or vested interests?}

Walker (1973, p.22) has identified six mechanisms for changing education programmes. These are rational debate, manipulation of funds by government bodies, administrative ruling, changing composition of student and/ or teaching bodies, student dissent and pressure from practising professionals. To date, it appears that New Zealand social work education programmes have changed in response to the latter five of these mechanisms, although student dissent and pressure from practising professionals have played very little overt part (compared to other countries) in New Zealand as yet.

When these five mechanisms are involved the change process is in danger of being governed by 'vested interests' of the groups involved (e.g. administrators, students, government bodies, practitioners, professional bodies, and university teachers). That is, change can be resisted by these groups unless their 'fixed commitments to rights, possessions and ideas from which (they) derive valued and even privileged benefits' are not threatened. 'Vested interests in our society often result in a trained incapacity that sabotages reality perception and efficiency of production and maintains obsolescent and wasteful practices' (Siporin, 1978, p.19).

Rational debate, on the other hand, would require the exposure of vested interests and alternative ideological positions. From this basis, choices could be made in relation to the implications of each position, or certain combinations of positions, for the type and quality of social work service made available to clients.

The choices available to social work education in New Zealand are presently being clarified. This paper has highlighted five alternative models for social work education and the implications of these alternatives for social work. It may be that New Zealand social work decides on one of these models or as Hunt (1978, p.7) suggests, a continuation of parts of these as we appear to have at present. Before any rational decisions can be made regarding the directions for the 1982 + period, more open debate, involving a wider group of social 
workers, and perhaps others (especially clients), is required. This debate could be a healthy and creative process 'provided the champions of rival systems of belief recognise that what each of them is upholding is not revealed and irrefutable truth, but a set of propositions that may be false and must therefore remain open to challenge' (Righton and Richards, 1979 , p.17, p.1).

\section{References}

Apple, M. (1979). Ideology and Curriculum. R.K.P.

Bernbaum, G. (1977). Knowledge and ideology in the sociology of education. MacMillan Press.

Crockett, J. (1977). Social work education in New Zealand: An historical and interpretative study. M.A. (Sociology) thesis, Auckland University.

Freire, P. (1972). Pedagogy of the oppressed. Penguin.

Freire, P. (1973). Education for critical consciousness. Seaburg Press.

Hardy, J. (1981). Values of social work. R.K.P.

Hunt, L. (1978). Social work and ideology. In N. Timms \& Watson (Ed.) Philosophy in social work. R.K.P.

Johnson, T. (1972). Professions and power. MacMillan.

Kendall, K. (1978). Reflections in social work education (1928-78). I.A.S.S.W.

Lusk. M. (1981). Philosophical changes in Latin American Social Work. International Social Work, XXIV(2), pp.1421.

McCreary, J. (1971). The school of social science - 'The martians and the minnions'. New Zealand Social Worker, 7(1), (Jan '71) and (2) (April '71).

Peters, R. (1970). Ethics and education.

Pritchard, C. \& Taylor, R. (1978). Social Work Reform or Revolution. R.K.P.

Pusic, E. (1976). Social realities - A world view. Paper presented at XVIII International Congress of Schools of Social Work 137.76.

Raynor, P. (1979). Brain washing students. Community Care, 26 April 79.

Resnick, R. (1980). Social work education in Latin America and the United States: A look to the future. Journal of Education for Social Work, 16(1), pp.104-111.

Righton, R. \& Richards, M. (1979). Social work education in conflict. N.I.S.W. Papers, No. 10.

Rochford, M. \& Robb, M. (1981). People in social services ANZ survey. N.Z.S.W.T.C.

Siporin, M. (1978). Practice theory and vested interests. Social Service Review, p. 418-436.

Social Work Training Council discussion papers (unpublished). Personal communication.

University Grants Committee Review Committee (1981). Social work education in New Zealand Universities.

Walker, W. (1973). The role of students, faculty and administration: and the development of more social programmes for the social profession. In H. Burlow (Ed.) Higher education and the social professions. University of Kentucky.

Wilensky, H. (1964). The professionalisation of everyone. American Journal of Sociology, 70, pp.142-6.

Williams, R. (1961). The long revolution. Chatto and Windus.

Young, M.D. (Ed.) (1971). Knowledge and control: New directions for the sociology of education. Collier MacMillan. 